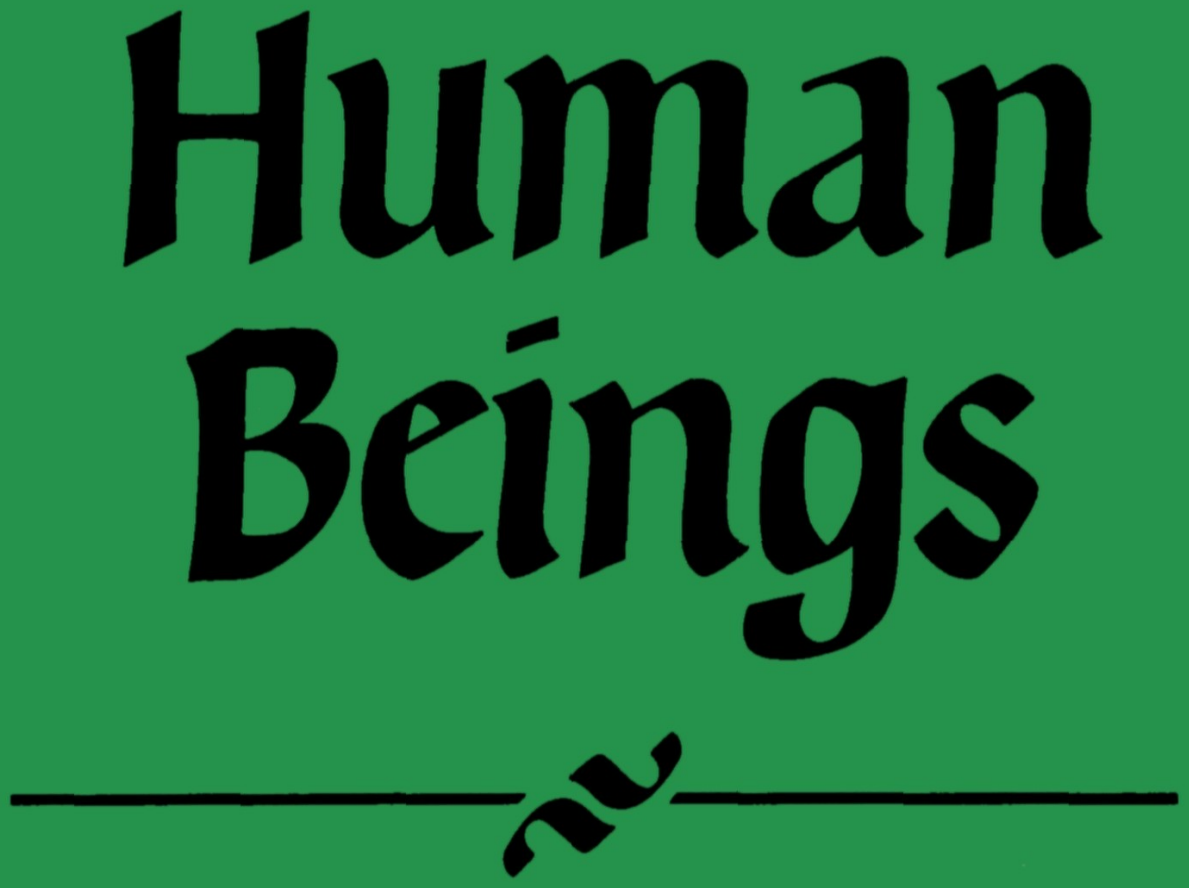

Edited by David

Cockburn 


\section{Human Beings}

EDITED BY

\section{David Cockburn}

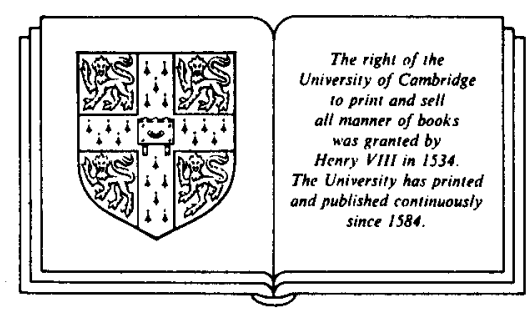

\section{CAMBRIDGE UNIVERSITY PRESS}

CAMBRIDGE

NEW YORK PORT CHESTER MELBOURNE SYDNEY 
Published by the Press Syndicate of the University of Cambridge The Pitt Building, Trumpington Street, Cambridge, CB2 1RP

40 West 20th Street, New York, NY 10011-4211, USA

10 Stamford Road, Oakleigh, Melbourne 3166, Australia

(C) The Royal Institute of Philosophy 1991

A catalogue record for this book is available from the British Library

ISBN 0521422450 (paperback)

Library of Congress Cataloguing in Publication Data

Data applied for 


\section{Contents}

Introduction 1

DAVID COCKBURN

Machines as Persons?

I CHRISTOPHERCHERRY

II OSWALD HANFLING $\quad 25$

The Importance of Being Human

I CORA DIAMOND

II DAVIDMCNAUGHTON

Response to McNaughton $\quad 83$

CORA DIAMOND

Response to Diamond $\quad 85$

DAVID MCNAUGHTON

Real Selves: Persons as a Substantial Kind $\quad 87$

E. J. LOWE

$\begin{array}{ll}\text { Personal Identity and Brain Transplants } & 109\end{array}$

P. F. SNOWDON

$\begin{array}{ll}\text { Personal Identity and the Idea of a Human Being } & 127\end{array}$ GEOFFREY MADELL

Imagination and the Sense of Identity 143 LARS HERTZBERG

Radical Critique, Scepticism and Commonsense 157 RAIMOND GAITA

Getting the Subject back into the World: Heidegger's Version 173 FERGUS KERR

Incarnational Anthropology 191 JOHN HALDANE

How Many Selves Make Me?

I. STEPHEN R. L. CLARK 213

II. KATHLEEN V. WILKES 235

Sartre and Our Identity as Individuals 245 ILHAM DILMAN 


\section{Contents}

$\begin{array}{ll}\text { Bibliography } & 265\end{array}$

$\begin{array}{ll}\text { Notes on Contributors } & 273\end{array}$

$\begin{array}{ll}\text { Index } & 275\end{array}$ 